\title{
Age related human $T$ cell subset evolution and senescence
}

\author{
Mingde $\mathrm{Li}^{1 \dagger}$, Danlin Yao ${ }^{1 \dagger}$, Xiangbo Zeng ${ }^{1}$, Dimitri Kasakovski ${ }^{1}$, Yikai Zhang ${ }^{1}$, Shaohua Chen ${ }^{1}$, Xianfeng Zha ${ }^{2}$, \\ Yangqiu Li ${ }^{1 *}$ and Ling $\mathrm{Xu}^{1,3^{*}}$
}

\begin{abstract}
T cells are fundamental effector cells against viruses and cancers that can be divided into different subsets based on their long-term immune protection and immediate immune response effects. The percentage and absolute number of these subsets change with ageing, which leads to a reduced immune response in older individuals. Stem cell memory T cells ( $\left.T_{S \mathrm{SM}}\right)$ represent a small population of memory T cells with enhanced proliferation and differentiation properties that are endowed with high potential for maintaining T cell homeostasis. However, whether these cells change with ageing and gender remains unknown. Here, we assayed the distribution of $\mathrm{T}_{\mathrm{SCM}}$ and other T cell subsets in peripheral blood from 92 healthy subjects (44 females and 48 males) ranging from 3 to 88 years old by flow cytometry. We found that $\mathrm{CD} 4+$ and $\mathrm{CD} 8+\mathrm{T}_{\mathrm{SCM}}$ in the circulation have relatively stable frequencies, and the absolute number of $\mathrm{CD} 8+\mathrm{T}_{\mathrm{SCM}}$ decreased with age; however, the ratio of $\mathrm{T}_{\mathrm{SCM}}$ to the $\mathrm{CD} 4+$ or CD8+ naïve population increased with age. Unlike the obvious changes in other T cell subsets with age and gender, the stable level of $\mathrm{T}_{\mathrm{Sc}}$ in peripheral blood may support their capacity for sustaining long-term immunological memory, while their importance may increase together with ageing.
\end{abstract}

Keywords: Stem cell memory T cell, Central memory T cells, Effector memory T cells, Ageing, Immunosenescence

\section{Background}

Immunosenescence is a complicated process. One discernible alteration is the number and composition of the different types of lymphocytes in the circulation, particularly $\mathrm{T}$ cells $[1-3]$. Conventionally, antigen-exposed $\mathrm{T}$ cells have been divided into central memory $\mathrm{T}$ $\left(\mathrm{T}_{\mathrm{CM}}\right)$ cells $(\mathrm{CD} 45 \mathrm{RO}+\mathrm{CCR} 7+)$, effector memory $\mathrm{T}$ $\left(\mathrm{T}_{\mathrm{EM}}\right)$ cells $(\mathrm{CD} 45 \mathrm{RO}+\mathrm{CCR7}-)$, and effector $\mathrm{T}\left(\mathrm{T}_{\mathrm{EF}}\right)$ cells (CD45RO-CCR7-). With ageing, continuous antigen stimulation and thymic involution lead to a shift in the $\mathrm{T}$ cell subset distribution from naïve $\mathrm{T}$ cells to $\mathrm{T}_{\mathrm{CM}}, \mathrm{T}_{\mathrm{EM}}$, and $\mathrm{T}_{\mathrm{EF}}$ [4]. This process is accompanied by the loss of expression of co-stimulatory molecules, such as CD27 and CD28. The results of these changes are likely to be associated with increased susceptibility to infections, autoimmune disorders, chronic diseases,

\footnotetext{
*Correspondence: yangqiuli@hotmail.com; lingxu114@163.com

${ }^{\dagger}$ Mingle Li and Danlin Yao contributed equally to this work.

'Department of Hematology, First Affiliated Hospital; Institute of Hematology, School of Medicine; Key Laboratory for Regenerative Medicine of Ministry of Education, Jinan University, No.601 West of Huangpu Avenue, Guangzhou 510632, China

Full list of author information is available at the end of the article
}

cardiovascular disease, and even cancers [5-9]. CD28, an important $\mathrm{T}$ cell co-stimulatory receptor, is responsible for $\mathrm{T}$ cell activation, proliferation, and survival. The accumulation of $\mathrm{CD} 28-\mathrm{T}$ cells, which mainly contribute to age-associated changes in $\mathrm{T}$ cells, is associated with a reduced overall immune response to pathogens and vaccines $[5,10]$.

Recently, a new memory $\mathrm{T}$ cell subset, stem cell memory $\mathrm{T}$ cells $\left(\mathrm{T}_{\mathrm{SCM}}\right)$, has been detected in humans. This subset was identified based on expression of the surface markers CD95 and CD28 on the CD45ROCCR7 + T cell subset [11]. Compared with other memory $\mathrm{T}$ cell subsets, $\mathrm{T}_{\mathrm{SCM}}$ demonstrates a faster response to antigen stimulation, preferentially survive after the elimination of antigens, stably persist for a long period of time, and reconstitute the entire peripheral $\mathrm{T}$ cell population with a small number of cells [12-14]. For instance, Marraco and colleagues found that a yellow fever virus (YFV)-specific $\mathrm{T}_{\mathrm{SCM}}$ population could stably maintain for more than 25 years in a man who received vaccination [15], while Costa del Amo also identified $\mathrm{T}_{\mathrm{SCM}}$ in the circulation possessing self-renewal capacity

(c) The Author(s). 2019 Open Access This article is distributed under the terms of the Creative Commons Attribution 4.0 International License (http://creativecommons.org/licenses/by/4.0/), which permits unrestricted use, distribution, and reproduction in any medium, provided you give appropriate credit to the original author(s) and the source, provide a link to the Creative Commons license, and indicate if changes were made. The Creative Commons Public Domain Dedication waiver (http://creativecommons.org/publicdomain/zero/1.0/) applies to the data made available in this article, unless otherwise stated. 
and clonal longevity, which are necessary for sustaining long-term immunological memory [16]. These studies supported that $\mathrm{T}_{\mathrm{SCM}}$ should play an important role in sustaining peripheral $\mathrm{T}$ cell homeostasis; however, whether $\mathrm{T}_{\mathrm{SCM}}$ could change with ageing has remained unclear. Thus, in this study, we analyzed age-related changes by comparing the CD4 and CD8 compartments in individuals with ageing throughout lifespan.

\section{Results and discussion}

The overall $\mathrm{T}$ cell reservoir decreases with age accompanied by an increase in the CD4 to CD8 ratio in the circulation

Immunosenescence is a multifactorial phenomenon that affects all compartments of the immune system. T cells are dramatically affected by ageing [3]. Based on age, we divided samples into 9 age groups with a span of 10 years. The results demonstrated that the absolute numbers of CD3+ $(P=0.0189)$ and CD $+(P=0.004)$ but not CD4+ $(P=0.1699) \mathrm{T}$ cells linearly decline with age, and differences between adjacent groups are not significant (Fig. 1a), indicating that the peripheral $\mathrm{T}$ cell reservoir gradually decreases with age, which is particularly obvious for the CD8+ T cell subset.

Due to the rapid decrease in CD8+ $\mathrm{T}$ cells with age, the ratio of $\mathrm{CD} 4$ to $\mathrm{CD} 8(\mathrm{CD} 4 / \mathrm{CD} 8)$ cells increased in the cohorts (Fig. 1b red line box and $\mathrm{C}$ ). Vasson et al. performed a comparative analysis of 300 healthy individuals from France, Austria, and Spain and found that France and Spain had a decreased CD4 to CD8 ratio with increasing age, and our data were most similar to the results from Austria. These authors thought it was possibly related to diet [17]. However, there was no information from Asia to compare relative differences. The distribution of the CD4/CD8 ratio in our study is shown in Fig. 1c, and there is a higher percentage of persons in the over 60 age group with a CD4/CD8 ratio in excess of two. Whether the increased CD4/CD8 ratio was related to the proliferation of regulatory $\mathrm{T}$ cells (Treg) and/or Th2 cells in older people remains unknown. As previously defined, an inverted $\mathrm{CD} 4 / \mathrm{CD} 8$ ratio $(<1: 1)$ is an immune risk factor for almost any age, and an inverted CD4:CD8 ratio is related to fewer B cells, expansion of late-differentiated or senescent $\mathrm{T}$ cells

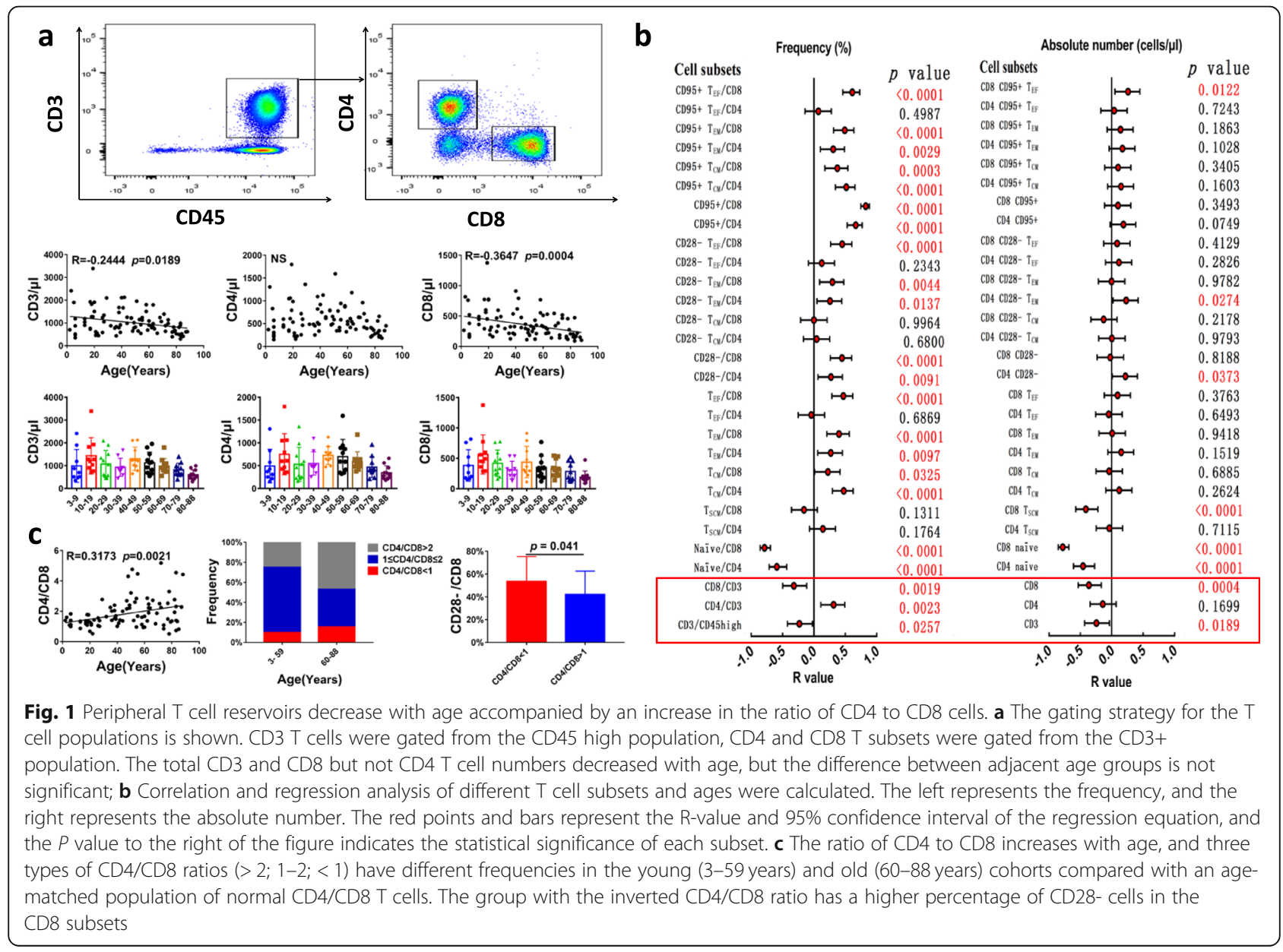


(CD8 + CD28-), and higher human cytomegalovirus (HCMV) seropositivity $[1,18]$. J Strindhall et al. reported that $8.0 \%$ of people aged $20-59$ years have an inverted $\mathrm{CD} 4 / \mathrm{CD} 8$ ratio, while $15.6 \%$ of those aged 60-90 years old have an inverted ratio [19]. These numbers are similar to our results where we also found a higher percentage of CD28- $\mathrm{T}$ cells in people with an inverted CD4/CD8 ratio in comparable age groups (Fig. 1c). In terms of HCMV infection, it was reported that the latent infection (IgG Seropositivity) rate in the Chinese population is more than 90\%, and even reaches $97.03 \%$ in Shanghai province (One of the first-tier cities of China) over age 25 [20]. We did not test for the human cytomegalovirus (HCMV) infection in these cohorts, but data from another project from our team showed that 36 out of 37 healthy individuals were seropositive for HCMV IgG (unpublished data). Based on these data, it is hard for us to analyze whether there are differences between HCMV infected and noninfected cohorts.

\section{An age-related $\mathrm{T}$ cell shift in distribution and $\mathrm{T}_{\mathrm{SCM}}$ homeostasis}

The gating strategy for $\mathrm{T}$ cells ranging from naïve to $\mathrm{T}_{\mathrm{EF}}$ cells is shown in Fig. 2a. Consistent with a previous study [4], our data also verified that the proportion of naive $\mathrm{T}$ cells in the $\mathrm{CD} 4+$ and $\mathrm{CD} 8+\mathrm{T}$ cell subsets sharply decrease with ageing, particularly for the CD8 population (Fig. 2b). With the exception of CD4+ $\mathrm{T}_{\mathrm{EF}}$ cells, the percentage of $\mathrm{T}_{\mathrm{CM}}, \mathrm{T}_{\mathrm{EM}}$, and $\mathrm{T}_{\mathrm{EF}}$ cells in the $\mathrm{CD} 4+$ and $\mathrm{CD} 8+\mathrm{T}$ cell subsets accumulated with age (Fig. 2b left, highlighted by red line box). For the absolute numbers in the different $\mathrm{T}$ cell subsets, with the exception of a decrease in $\mathrm{CD} 4+$ and $\mathrm{CD} 8+$ naïve $\mathrm{T}$ cells with age, there was no difference in the other subsets (Fig. 2b right, highlighted by red line box). Moreover, the decrease in naïve $\mathrm{T}$ cells could be found both in the percentage and absolute number level, indicating that ageing has quite a large impact on the homeostasis of naïve $\mathrm{T}$ cells. Due to the erosion of the thymus beginning at approximately age 20 , less naive $\mathrm{T}$ cells can be produced, and the increasing antigens that have been

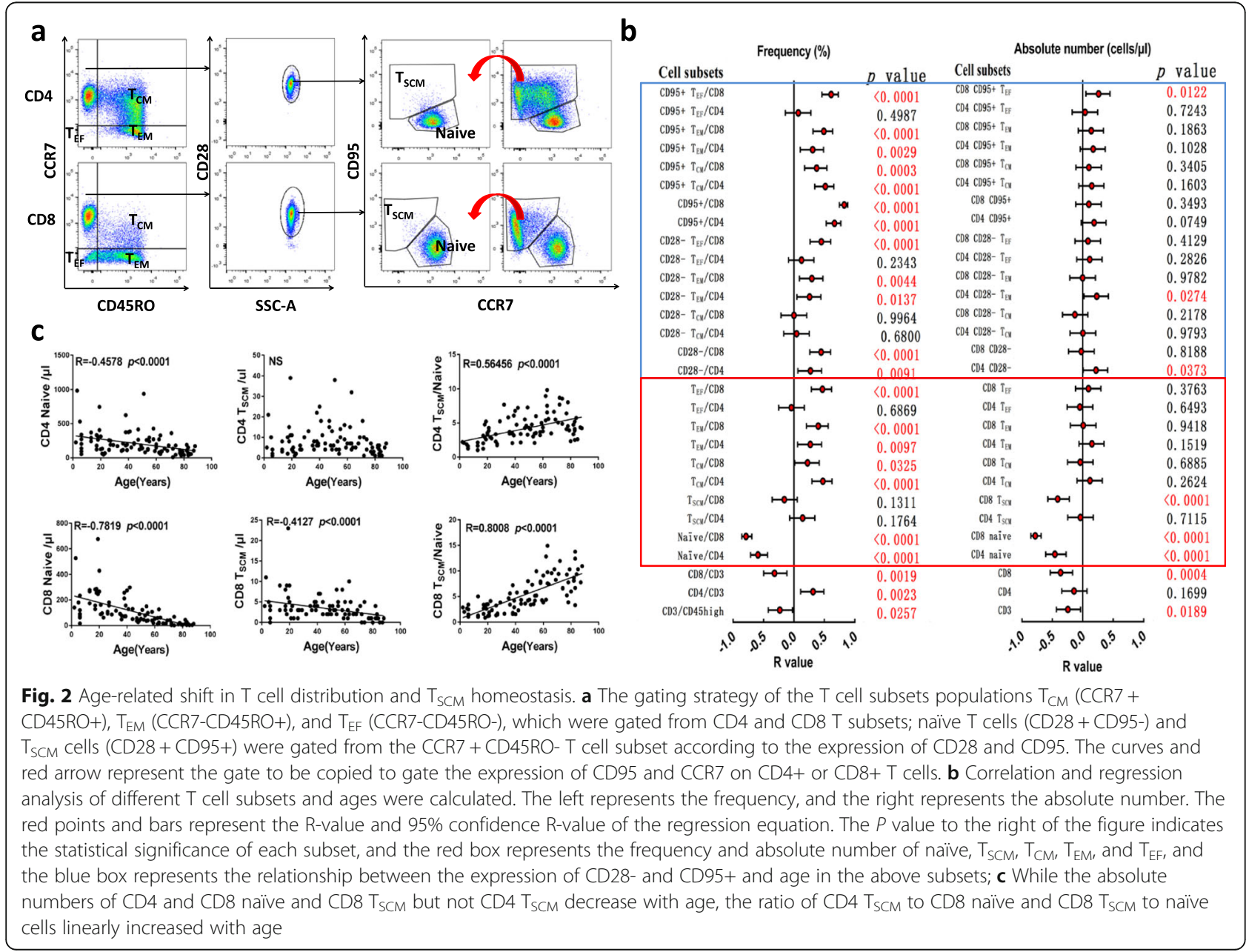


encountered and infections that have occurred during the lifespan contribute to the differentiation of naïve $\mathrm{T}$ cells into more differentiated $\mathrm{T}$ cell subsets. When examining different memory $\mathrm{T}$ cell subsets, only the percentage of changes can be detected without apparent changes in absolute cell number, and this is partially due to the diversion in the subsets analyzed. In addition, the decrease in total CD8 $\mathrm{T}$ cell number further diluted the change in cell number for each subset. These results indicate that both the percentage and number of naïve $\mathrm{T}$ cells are physiologically related to ageing, while the composition of $\mathrm{CD} 4$ and $\mathrm{CD} 8 \mathrm{~T}$ cell subsets also reflect the immune situation in individuals to different degrees.

$\mathrm{T}_{\mathrm{SCM}}$ is a newly defined $\mathrm{T}$ cell subset with the capacities of self-renewal and differentiation into various memory/effector subsets, and this cell type provides a potential reservoir for $\mathrm{T}$ cell memory throughout life [21, 22]. In our previous studies, we found a lower proportion of $\mathrm{T}_{\mathrm{SCM}}$ in patients with acute or chronic myeloid leukemia compared with age-matched healthy individuals [7, 8]; however, little is known about the $\mathrm{T}_{\mathrm{SCM}}$ changes with age. Here, we found that $\mathrm{T}_{\mathrm{SCM}}$ cells account for $1.27 \pm 0.55 \%$ of the $\mathrm{CD} 4$ and $0.98 \pm 0.53 \%$ of the CD8 population, and the absolute numbers of $\mathrm{CD} 4+$ and $\mathrm{CD} 8+\mathrm{T}_{\mathrm{SCM}}$ cells in peripheral blood were $7.97 \pm 7.32 / \mu \mathrm{l}$ and $3.44 \pm 3.14 / \mu \mathrm{l}$, respectively. The absolute number of CD8+ $\mathrm{T}_{\mathrm{SCM}}$ decrease with age (Fig. $2 \mathrm{~b}$ and c). What is interesting is that although the absolute number of naive $\mathrm{T}$ cells sharply decrease with age, the ratio of CD4+ $\mathrm{T}_{\mathrm{SCM}} / \mathrm{CD} 4+\mathrm{T}_{\mathrm{N}}$ and $\mathrm{CD} 8+\mathrm{T}_{\mathrm{SCM}} / \mathrm{CD} 8+\mathrm{T}_{\mathrm{N}}$ cells linearly increase, particularly for $\mathrm{CD} 8+\mathrm{T}_{\mathrm{SCM}}$ (Fig. 2c).
These results indicate that $\mathrm{CD} 4+\mathrm{T}_{\mathrm{SCM}}$ are more stable than $\mathrm{CD} 8+\mathrm{T}_{\mathrm{SCM}}$, which may explain the slower senescence of the CD4+ T cell subset compared with the CD8 population. Furthermore, although the number of $\mathrm{CD} 8+\mathrm{T}_{\mathrm{SCM}}$ decreased with age, the rate of decrease was slower than that of the naïve population. Considering thymus erosion and naïve $\mathrm{T}$ cell contraction together with ageing [23], it is reasonable to suspect that $\mathrm{T}_{\mathrm{SCM}}$ may provide a large contribution to maintaining the homeostasis of peripheral $\mathrm{T}$ cell subsets during ageing due to their strong self-renewal and differentiation ability. It appears that the homeostasis of the CD4 population is more stable than that of the CD8 population due to the stable number of $\mathrm{CD} 4+\mathrm{T}_{\mathrm{SCM}}$ in one's lifetime.

We also analyzed changes in the co-stimulatory molecules CD28 and FAS (CD95) on the T cell subsets with age. As shown in Fig. $2 \mathrm{~b}$ left (highlighted by a blue line box), the percentages of the CD28- and CD95+ T cell subsets in the CD4 and CD8 populations accumulated with age, but only the CD4+CD28- $\mathrm{T}$ cells had an increase in absolute number. In addition, the increase in different sub-populations demonstrated different characteristics where it appears that the CD4 $\mathrm{T}_{\mathrm{EM}}$ subset has more profound accumulation of CD28- $\mathrm{T}$ cells, while the $\mathrm{CD} 8 \mathrm{~T}_{\mathrm{EF}}$ subset has a more apparent increase in CD95+ T cells (Fig. 2b left and right, highlighted by a blue line box), which may be due to the change in both percentage and absolute number. Considering that CD28 plays an important role in $\mathrm{T}$ cell proliferation and activation, the accumulation of $\mathrm{CD} 28-\mathrm{CD} 4+\mathrm{T}$ cells

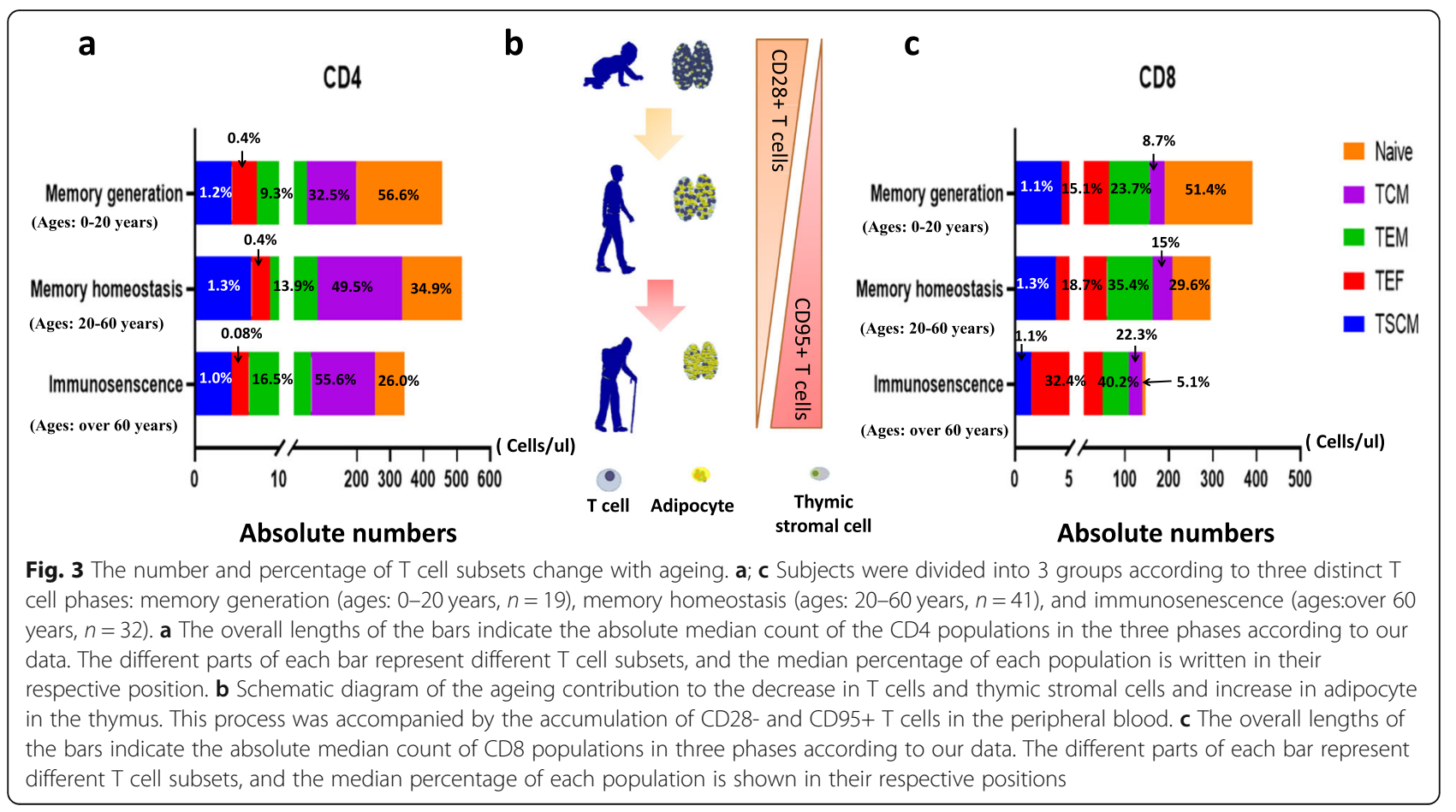


Table 1 Characteristics of healthy volunteers

\begin{tabular}{lllllllllll}
\hline Variable & \multicolumn{10}{l}{ Total } \\
\hline Age/year & $3-9$ & $10-19$ & $20-29$ & $30-39$ & $40-49$ & $50-59$ & $60-69$ & $70-79$ & $80-88$ & $3-88$ \\
Number & 9 & 10 & 11 & 9 & 10 & 11 & 11 & 10 & 11 & 92 \\
Male & 5 & 6 & 7 & 5 & 5 & 5 & 5 & 4 & 6 \\
Female & 4 & 4 & 4 & 4 & 5 & 6 & 6 & 6 & 5 & 44 \\
\hline
\end{tabular}

alone with ageing may be an adverse indication for older individuals. In addition, CD95 (Fas) can lead to apoptosis in target cells when it binds to Fas-ligand (Fas-L); thus, the accumulation of the Fas $+\mathrm{CD} 8+\mathrm{T}_{\mathrm{EF}}$ population may partially explain the sharp decrease in CD8+ $\mathrm{T}$ cells with ageing compared with CD4+ T cells.

Studies examining gender-dependent changes demonstrated that females produce higher antibody levels and have a higher number of CD4+ T cells than males [24, 25]. Here, we also analyzed the differences in the $\mathrm{T}$ cell subset distribution of three age groups $(<20$ years; $20-60$ years; > 60 years) between females and males. The results show that males in the $20-60$ years group have a higher $\mathrm{CD} 8$ naïve $\mathrm{T}$ cell proportion and absolute count compared with females $(p<0.05)$, while males in the $>60$ years group have a higher proportion of CD4 naïve $\mathrm{T}$ cells and a lower proportion of CD95 + CD4 $\mathrm{T}$ cells compared with females. We then further compared the differences in all of the subjects based on sex and found similar results where a higher CD8 naïve $\mathrm{T}$ cell proportion and absolute count were found for males in comparison with females $(p<0.05)$, while males had a lower proportion of $\mathrm{CD} 8+\mathrm{T}_{\mathrm{EF}}$ and $\mathrm{CD} 28-\mathrm{CD} 8+\mathrm{T}$ cells compared with females (Additional file 1: Table S1 and Additional file 2: Table S2). These results are interesting and may indicate slower thymus erosion in males and a higher antigen resistant capacity for males compared with females over age 20; however, larger sample analysis is required in the future to confirm this finding.

Based on changes in memory $\mathrm{T}$ cell frequency, pathogen susceptibility and mortality throughout human life, Farber et al. divided an individual's lifetime into three phases: memory generation (ages $0-20$ years), memory homeostasis (ages 20-65 years), and immunosenescence (age > 65 years) [26]. We first summarized the CD4+ and $\mathrm{CD} 8+\mathrm{T}$ cell changing characteristics in Chinese cohorts based on the three phases (Fig. 3). The total number of $\mathrm{CD} 8+\mathrm{T}$ cells were more apparently reduced compared with CD4+ $\mathrm{T}$ cells across the human lifespan in peripheral blood, and in the sub-population, naive $\mathrm{T}$ cells sharply decreased while $\mathrm{T}_{\mathrm{CM}}, \mathrm{T}_{\mathrm{EM}}$, and $\mathrm{T}_{\mathrm{EF}}$ accumulated with age (Fig. $3 \mathrm{a}$ and $\mathrm{c}$ ). Although the absolute number of $\mathrm{CD} 8+\mathrm{T}_{\mathrm{SCM}}$ decreased with age, the percentage of $\mathrm{CD} 4+$ and $\mathrm{CD} 8+\mathrm{T}_{\mathrm{SCM}}$ could maintain a stable level throughout the lifespan. At the same time, CD28- and CD95+ $\mathrm{T}$ cells also accumulated, which could result in a loss of activation and proliferation potential in $\mathrm{T}$ cells
(Fig. 3b). These findings indicate that although $\mathrm{T}$ cell reservoirs and function decrease with age, the stable level of $\mathrm{CD} 8+\mathrm{T}_{\mathrm{SCM}}$ frequency may be quite important in older people for maintaining the homeostasis of peripheral $\mathrm{T}$ cell memory; however, much work remains to be done in the future to clearly understand the importance of $\mathrm{T}_{\mathrm{SCM}}$ in humans, such as whether $\mathrm{T}_{\mathrm{SCM}}$ cells can divide in a self-renewal manner at the clonal level or not?

\section{Materials and methods \\ Sample information}

Peripheral blood (PB) samples were obtained from the Department of the clinical laboratory, First Affiliated Hospital of Jinan University. Subjects had a current or recent acute infection, and those with autoimmune disease or diabetes mellitus were excluded. Ninety-two healthy volunteers ( 44 females and 48 males) ranging from 3 to 88 years old were enrolled. There were 9 different age groups with a span of 10 years. The characteristics of the healthy volunteers are listed in Table 1 . The age ranges for each of the groups were as follows: 3-9 years $(n=9) ; 10-19$ years $(n=10) ; 20-29$ years $(n=11) ; 30-39$ years $(n=9) ; 40-49$ years $(n=10) ; 50$ 59 years $(n=11) ; 60-69$ years $(n=11) ; 70-79$ years $(n=10)$; and $80-88$ years $(n=11)$. All procedures were conducted according to the guidelines of the Medical Ethics Committees of the Health Bureau of the Guangdong Province in China, and ethical approval was obtained from the Ethics Committee of the Medical School of Jinan University.

\section{Immunophenotyping analysis by flow cytometry}

Cell surface staining for flow cytometry was performed using the following antibodies: CD45-APC, CD3-FITC, CD4-APC-H7, CD8-Percp-Cy5.5, CD28-PE, CD95-PECy7, CCR7-BV421, CD45RO-BV510, a BV510 isotype Control, and a BV421 isotype Control. Extracellular staining was performed according to the manufacturer's instructions. The CCR7-BV421 fluorescent antibody was stained independently. Twenty microliters of absolute count microsphere (Thermo; Cat: C36950) was added to samples for absolute number analysis. Cells were analyzed with a BD Verse flow cytometer (BD, Biosciences, USA), and data analysis was performed using FlowJo software. 


\section{Statistical analyses}

All data are represented as median, and statistically significant differences between the different $\mathrm{T}$ cell populations and between CD28- and CD95+ T cells were analyzed by the Mann-Whitney $U$ test for nonparametric values. Calculations were performed using GraphPad Prism version 7.00 software and SPSS 23.

\section{Additional files}

Additional file 1: Table S1. The difference of T cell frequencies compared between male and female at three age groups. (DOCX $47 \mathrm{~kb}$ )

Additional file 2: Table S2. The difference $T$ cell absolute number compared between male and female at three age groups. (DOCX 46 kb)

\section{Abbreviations}

CMV: Cytomegalovirus; $T_{C M}$ : Central memory T cell; $T_{\mathrm{EF}}$ : Effector $\mathrm{T}$ cell; $T_{E M}$ : Effector memory $T$ cell; $T_{N}$ : Naïve $T$ cell; Treg: Regulatory $T$ cell; $\mathrm{T}_{\mathrm{SCM}}$ : Stem cell memory $T$ cells

\section{Acknowledgments}

We want to thank the flow facility of the Biological Translational Research Institute of Jinan University as well as Hui Zhang, a research assistant from the Translational Research Institute of Jinan University. We would also like to thank the volunteers who donated blood for this project.

\section{Authors' contributions}

$\mathrm{LX}$ and YQL contributed to the concept development and study design. MDL, DLY, XBZ, DK, YKZ, and SHC performed laboratory studies. XFZ collected the heathy subject data. MDL and DLY contributed to figure preparation. $\mathrm{XL}, \mathrm{YQL}, \mathrm{DLY}$, and $\mathrm{MDL}$ drafted the manuscript. All authors read and approved the final manuscript.

\section{Funding}

This study was supported by grants from the National Natural Science Foundation of China (Nos. 81770152, 91642111, and 81570143), China postdoctoral science foundation (No. 2018M640884), the Guangdong Provincial Applied Science and Technology Research \& Development Program (No. 2016B020237006), the Guangzhou Science and Technology Project (Nos. 201807010004 and 201803040017), and Jinan University 'national undergraduate innovative experimental program' project (No. 201810559027).

\section{Availability of data and materials}

The datasets used and/or analyzed during the current study are available from the corresponding author upon reasonable request.

\section{Ethics approval and consent to participate}

The study was approved by the ethics committee of The First Affiliated Hospital of Jinan University.

\section{Consent for publication}

Not applicable

\section{Competing interests}

The authors declare that they have no competing interests.

\section{Author details}

${ }^{1}$ Department of Hematology, First Affiliated Hospital; Institute of Hematology, School of Medicine; Key Laboratory for Regenerative Medicine of Ministry of Education, Jinan University, No.601 West of Huangpu Avenue, Guangzhou 510632, China. ${ }^{2}$ Department of Clinical Laboratory, First Affiliated Hospital, Jinan University, Guangzhou 510632, China ${ }^{3}$ The Clinical Medicine Postdoctoral Research Station, Jinan University, Guangzhou 510632, China.
Received: 16 May 2019 Accepted: 28 August 2019

Published online: 11 September 2019

\section{References}

1. Aw D, Silva $A B$, Palmer DB. Immunosenescence: emerging challenges for an aging population. Immunology. 2007;120(4):435-46.

2. Bektas A, Schurman SH, Sen R, Ferrucci L. Human T cell immunosenescence and inflammation in aging. J Leukoc Biol. 2017;102(4):977-88.

3. Del Giudice G, Goronzy JJ, Grubeck-Loebenstein B, Lambert PH, Mrkvan T, Stoddard JJ, Doherty TM. Fighting against a protean enemy: immunosenescence, vaccines, and healthy aging. NPJ Aging Mech Dis. 2018;4:1

4. Saule P, Trauet J, Dutriez V, Lekeux V, Dessaint JP, Labalette M. Accumulation of memory $T$ cells from childhood to old age: central and effector memory cells in CD4(+) versus effector memory and terminally differentiated memory cells in CD8(+) compartment. Mech Ageing Dev. 2006;127(3):274-81.

5. Weng NP, Akbar AN, Goronzy J. CD28(-) T cells: their role in the ageassociated decline of immune function. Trends Immunol. 2009;30(7):306-12.

6. Moro-Garcia MA, Echeverria A, Galan-Artimez MC, Suarez-Garcia FM, SolanoJaurrieta JJ, Avanzas-Fernandez P, Diaz-Molina B, Lambert JL, Lopez-Larrea C, Moris de la Tassa $C$, et al. Immunosenescence and inflammation characterize chronic heart failure patients with more advanced disease. Int $J$ Cardiol. 2014:174(3):590-9.

7. Yao D, Xu L, Tan J, Zhang Y, Lu S, Li M, Lu S, Yang L, Chen S, Chen J, et al. Re-balance of memory $T$ cell subsets in peripheral blood from patients with CML after TKI treatment. Oncotarget. 2017;8(47):81852-9.

8. Xu L, Yao D, Tan J, He Z, Yu Z, Chen J, Luo G, Wang C, Zhou F, Zha X, et al. Memory $T$ cells skew toward terminal differentiation in the CD8+ $\mathrm{T}$ cell population in patients with acute myeloid leukemia. J Hematol Oncol. 2018;11(1):93.

9. Fang P, Li X, Dai J, Cole L, Camacho JA, Zhang Y, Ji Y, Wang J, Yang XF, Wang $\mathrm{H}$. Immune cell subset differentiation and tissue inflammation. J Hematol Oncol. 2018;11(1):97

10. Kasakovski D, Xu L, Li Y. T cell senescence and CAR-T cell exhaustion in hematological malignancies. J Hematol Oncol. 2018;11(1):91.

11. Stemberger C, Neuenhahn M, Gebhardt FE, Schiemann M, Buchholz VR, Busch DH. Stem cell-like plasticity of naive and distinct memory CD8+ T cell subsets. Semin Immunol. 2009:21(2):62-8.

12. Zhang $Y$, Joe $G$, Hexner E, Zhu J, Emerson SG. Host-reactive CD8+ memory stem cells in graft-versus-host disease. Nat Med. 2005;11(12):1299-305.

13. Gattinoni L, Lugli E, Ji Y, Pos Z, Paulos CM, Quigley MF, Almeida JR, Gostick E, Yu Z, Carpenito C, et al. A human memory T cell subset with stem celllike properties. Nat Med. 2011:17(10):1290-7.

14. Lugli E, Gattinoni L, Roberto A, Mavilio D, Price DA, Restifo NP, Roederer M. Identification, isolation and in vitro expansion of human and nonhuman primate T stem cell memory cells. Nat Protoc. 2013;8(1):33-42.

15. Marraco SAF, Soneson C, Cagnon L, Gannon PO, Allard M, Maillard SA, Montandon N, Rufer N, Waldvogel S, Delorenzi M, et al. Long-lasting stem cell-like memory CD8(+) T cells with a naive-like profile upon yellow fever vaccination. Sci Transl Med. 2015:7(282):282ra48

16. Costa Del Amo P, Lahoz-Beneytez J, Boelen L, Ahmed R, Miners KL, Zhang Y, Roger L, Jones RE, Marraco SAF, Speiser DE, et al. Human TSCM cell dynamics in vivo are compatible with long-lived immunological memory and stemness. PLoS Biol. 2018;16(6):e2005523.

17. Vasson MP, Farges MC, Goncalves-Mendes N, Talvas J, Ribalta J, WinklhoferRoob B, Rock E, Rossary A. Does aging affect the immune status? A comparative analysis in 300 healthy volunteers from France, Austria and Spain. Immun Ageing. 2013:10(1):38.

18. Derhovanessian E, Larbi A, Pawelec G. Biomarkers of human immunosenescence: impact of Cytomegalovirus infection. Curr Opin Immunol. 2009;21(4):440-5.

19. Strindhall J, Skog M, Ernerudh J, Bengner M, Lofgren S, Matussek A Nilsson $\mathrm{BO}$, Wikby $\mathrm{A}$. The inverted CD4/CD8 ratio and associated parameters in 66-year-old individuals: the Swedish HEXA immune study. Age (Dordr). 2013:35(3):985-91.

20. Fang $F Q$, Fan QS, Yang ZJ, Peng YB, Zhang L, Mao KZ, Zhang Y, Ji YH. Incidence of cytomegalovirus infection in Shanghai, China. Clin Vaccine Immunol. 2009;16(11):1700-3.

21. Lugli E, Dominguez MH, Gattinoni L, Chattopadhyay PK, Bolton DL Song K, Klatt NR, Brenchley JM, Vaccari M, Gostick E, et al. Superior T 
memory stem cell persistence supports long-lived T cell memory. J Clin Invest. 2013;123(2):594-9.

22. Xu L, Zhang Y, Luo G, Li Y. The roles of stem cell memory $T$ cells in hematological malignancies. J Hematol Oncol. 2015;8:113.

23. Goronzy JJ, Fang FQ, Cavanagh MM, Qi Q, Weyand CM. Naive T cell maintenance and function in human aging. J Immunol. 2015;194(9):4073-80

24. Andreu-Ballester JC, Garcia-Ballesteros C, Benet-Campos C, Amigo V, AlmelaQuilis A, Mayans J, Ballester F. Values for alphabeta and gammadelta Tlymphocytes and CD4+, CD8+, and CD56+ subsets in healthy adult subjects: assessment by age and gender. Cytometry B Clin Cytom. 2012; 82(4):238-44.

25. Whitacre CC, Reingold SC, O'Looney PA. A gender gap in autoimmunity Science. 1999;283(5406):1277-8.

26. Farber DL, Yudanin NA, Restifo NP. Human memory T cells: generation, compartmentalization and homeostasis. Nat Rev Immunol. 2014;14(1):24-35.

\section{Publisher's Note}

Springer Nature remains neutral with regard to jurisdictional claims in published maps and institutional affiliations.

Ready to submit your research? Choose BMC and benefit from:

- fast, convenient online submission

- thorough peer review by experienced researchers in your field

- rapid publication on acceptance

- support for research data, including large and complex data types

- gold Open Access which fosters wider collaboration and increased citations

- maximum visibility for your research: over $100 \mathrm{M}$ website views per year

At BMC, research is always in progress.

Learn more biomedcentral.com/submissions 